Tropical Journal of Pharmaceutical Research, August 2009; 8 (4): 337-344

(C) Pharmacotherapy Group,

Faculty of Pharmacy, University of Benin,

Benin City, 300001 Nigeria.

All rights reserved.

Research Article

Available online at http://www.tjpr.org

\title{
Effect of Aqueous Extract of Nutmeg on Hyperglycaemia, Hyperlipidaemia and Cardiac Histology Associated with Isoproterenol-induced Myocardial Infarction in Rats
}

\section{Mohammed Abdul Kareem*, Gadhamsetty Saayi Krushna, Shaik Althaf Hussain and Kodidhela Lakshmi Devi}

Department of Biochemistry, S.K. University, Anantapur, Andhra Pradesh, India-515003.

\begin{abstract}
Purpose: The present study was designed to evaluate the hypoglycaemic and hypolipidaemic activities of the aqueous extract of nutmeg (i.e., the kernel of Myristica fragrans) in rat models against myocardial infarction (MI) induced by isoproterenol (ISO).

Methods: Rats were pretreated with nutmeg extract (NM) at an oral dose of $100 \mathrm{mg} / \mathrm{kg} /$ day for a period of 30 days, followed by the induction of MI by subcutaneous administration of ISO (85 mg/kg) for two consecutive days. The heart tissue was excised immediately, washed with chilled isotonic saline and used in histopathological studies. Blood was also collected from the animals and the plasma separated was subjected to biochemical analysis.

Results: In ISO-administered group, a significant $(p<0.05)$ increase in the levels of blood glucose, plasma lipids and lipoprotein lipase activity was observed along with hyalinization of muscle fibres, compared NM-pretreated ISO-administered rats. In rats treated with NM, biochemical parameters were near normal. Histological studies revealed reduced damage of heart tissue in ISO-administered rats that were pretreated with NM.

Conclusion: NM possesses protected rats against hyperglycaemia, hyperlipidaemia and cardiac tissue damage following MI. Therefore, NM should be further investigated as a prophylactic against the risk of MI.
\end{abstract}

Key words: Isoproterenol; Myocardial infarction; Glucose; Lipids; Lipoprotein lipase; Nutmeg; Myristica fragrans.

*Corresponding author: E-mail: dkarry.kareem@gmail.com; Tel: 91-08554-255879; Fax: 91-08554255244 


\section{INTRODUCTION}

Cardiovascular diseases (CVD) remain the principal cause of death in both developed and developing countries, accounting for roughly $20 \%$ of all annual deaths worldwide. Myocardial infarction (MI) is the rapid development of myocardial necrosis caused by critical imbalance between oxygen supply and the demand of the myocardium. Oxidative stress resulting from increased production of free radicals associated with decreased levels of antioxidants in the myocardium plays a major role in CVD such as ischemic heart disease, atherosclerosis, congestive heart failure, cardiomyopathy and arrhythmias $^{1}$. Damage to the myocardial cells occurs due to the generation of toxic reactive oxygen species (ROS) such as superoxide anion, hydrogen peroxide and hydroxyl radical $^{2}$.

Isoproterenol (ISO), a synthetic catecholamine and $\beta$-adrenoceptor agonist, has been found to cause severe stress in the myocardium resulting in infarct-like necrosis ${ }^{3}$. Among the various mechanisms proposed to explain the ISO-induced cardiac damage, generation of highly cytotoxic free radicals through the auto-oxidation of the drug has been proposed as one of the important causative factors ${ }^{4}$. The consumption of diets rich in plant foods is associated with reduced risk of CVD, and this has been observed in numerous epidemiological studies ${ }^{5}$.

Spices have been used since ancient times not only for increasing the flavor of foods but also for their preservative and medicinal properties. Myristica fragrans (family: Myristicaceae) is a tropical, evergreen tree native to the Moluccas or Spice Island of Indonesia. Nutmeg is the dried seed kernel of Myristica fragrans and is widely used as spice and also to flavor many kinds of baked goods and vegetables. Nutmeg possesses antifungal, hepatoprotective ${ }^{6}$ and antioxidant properties $^{7}$. Recent studies indicate that it is useful against damage caused by gamma radiation $^{8}$ and also in the improvement of mouse memory ${ }^{9}$. Anti-inflammatory ${ }^{10}$, antidysentric $^{11}$, analgesic and hypotensive ${ }^{12}$ activities of nutmeg have also been reported, in addition to its insulin-like biological activity $^{13}$.

The present work seeks to investigate the protective effect of the aqueous extract of nutmeg (NM) on rats in which $\mathrm{Ml}$ was induced by ISO,

\section{MATERIALS AND METHODS}

\section{Materials}

NM was received as a gift from Chemiloids (batch no: SR/KN/CL/1/2007), manufacturers and exporters of chemicals, alkaloids and herbal extracts, based in Vijayawada, Andhra Pradesh, India.

\section{Animals and Experimental protocol}

Adult male rats of Wistar strain, weighing 120-150g, were procured from the National Centre for Animal Science, National Institute of Nutrition, Hyderabad, India. The study was approved by Animal Ethics Committee of S.K.University, Anantapur (Reg. no. 470/01/a/CPCSEA). The rats were fed with commercial pellet rat chow $(\mathrm{M} / \mathrm{s}$. Hindustan Lever Ltd., Mumbai, India) and water ad libitum and maintained under standard laboratory conditions with $12: 12 \mathrm{~h}$ light : dark cycle. The rats were divided into four groups of eight animals each. Group I rats served as positive control received $1 \mathrm{ml}$ of physiological saline subcutaneously (sc) for two days while group II rats were administered ISO sc (85 $\mathrm{mg} / \mathrm{kg}$ body weight/day ${ }^{14}$ ) dissolved in physiological saline twice at an interval of 24 h for two consecutive days. Group III rats were pretreated with NM orally $(100 \mathrm{mg} / \mathrm{kg}$ bw/day) for a period of 30 days while group IV rats were pretreated with NM orally (100 $\mathrm{mg} / \mathrm{kg}$ bw for a period of 30 days) and then received ISO $85 \mathrm{mg} / \mathrm{kg}$ bw/ day dissolved in physiological saline sc twice at an interval of $24 \mathrm{~h}$ for two consecutive days. 
At the end of 30 days, the animals were fasted for 12 hours to minimize dietary effects and anaesthetized with thiopentone sodium (35 mg/kg bw, ip). Blood was drawn from the external jugular vein of the rats into heparinised tubes and plasma was separated from the cells by centrifugation at $3000 \mathrm{rpm}$ for $10 \mathrm{~min}$ and immediately used for the estimation of glucose and lipids. The heart tissue was excised immediately, washed with chilled isotonic saline and used in histopathological studies.

\section{Plasma glucose determination}

Plasma glucose was estimated by GOD-POD enzymatic method using Monozyme diagnostic kit, which is based on Trinders's method $^{15}$. To $10 \mu \mathrm{l}$ of plasma, $1.0 \mathrm{ml}$ of enzyme reagent was added, mixed and incubated at $37^{\circ} \mathrm{C}$ for $10 \mathrm{~min}$, and then $1 \mathrm{ml}$ of distilled water was added. A series of glucose standards ranging from 0.2 to $1.0 \mathrm{ml}$ was placed in test tubes and made up to $1.0 \mathrm{ml}$ with distilled water. One $\mathrm{ml}$ of the enzyme reagent was added to the standards and incubated at $37^{\circ} \mathrm{C}$ for $10 \mathrm{~min}$. followed by the addition of $1.0 \mathrm{ml}$ of distilled water.The red color was read spectrophotometrically at 505 $\mathrm{nm}$ against blank (distilled water) and the results were expressed as $\mathrm{mg} / 100 \mathrm{ml}$.

\section{Total cholesterol assessment}

Plasma total cholesterol was estimated by enzymatic method using Monozyme diagnostic kit, as described by Allian et $\mathrm{al}^{16}$ To $1.0 \mathrm{ml}$ of freshly reconstituted enzyme reagent, $0.01 \mathrm{ml}$ of plasma was added, mixed well and incubated at $37^{\circ} \mathrm{C}$ for $5 \mathrm{~min}$. Extinction was measured spectrophotometrically at $505 \mathrm{~nm}$ against the blank (distilled water). The results were expressed as $\mathrm{mg} / 100 \mathrm{ml}$.

\section{Triglycerides determination}

Plasma triglycerides were estimated by enzymatic method using Monozyme diagnostic kit, based on the technique of
Fossati and Principe ${ }^{17}$. To $0.01 \mathrm{ml}$ of plasma, $1.0 \mathrm{ml}$ of the reagent was added, mixed and incubated at $37^{\circ} \mathrm{C}$ for $10 \mathrm{~min}$. Triglyceride standard and blank (distilled water) were also treated in a similar manner. Absorbance was read at 510nm and the values expressed as $\mathrm{mg} / \mathrm{dl}$.

\section{Free fatty acids evaluation}

Plasma free fatty acids were estimated by the method of Itaya and $\mathrm{Ui}^{18}$. To $6 \mathrm{ml}$ of chloroform in a glass-stoppered tube, $1 \mathrm{ml}$ of $0.5 \mathrm{M}$ phosphate buffer $(\mathrm{pH} 6.5)$ and $0.2 \mathrm{ml}$ of plasma were added. The tubes were shaken for $90 \mathrm{sec}$, allowed to stand for $15 \mathrm{~min}$ and centrifuged. The chloroform layer was transferred to another stoppered tube and $3 \mathrm{ml}$ of $\mathrm{Cu}$ triethanolamine reagent was added. Tubes were allowed to stand for 15 min and centrifuged. The choloroform layer was filtered through Whatman No 1 filter paper. To the filtrate, $0.2 \mathrm{ml}$ of $0.4 \%$ sodium diethyl dithiocarbomate was added. The intensity of the color developed was read against reagent blank at $440 \mathrm{~nm}$. Standard solutions of palmitic acid were run under similar conditions and the concentration of the sample calculated was expressed as $\mathrm{mg} / \mathrm{dl}$.

\section{Phospholipids}

Total plasma phospholipids were estimated by the method of Connerty ${ }^{19}$. To $1.0 \mathrm{ml}$ of plasma, $16 \mathrm{ml}$ of ethanol-ether mixture (3:1 $\mathrm{v} / \mathrm{v})$ was added dropwise with constant shaking. It was heated carefully to boiling, cooled, made up to $20 \mathrm{ml}$ with more ethanolether mixture and filtered. $8.0 \mathrm{ml}$ of the filtrate was taken and evaporated to dryness over hot water bath. To the residue, $1.0 \mathrm{ml}$ of conc. sulphuric acid $\left(\mathrm{H}_{2} \mathrm{SO}_{4}\right)$ was added and heated gently. When the mixture turned brown, a drop of hydrogen peroxide $\left(\mathrm{H}_{2} \mathrm{O}_{2}\right)$ was added, heated further and $\mathrm{H}_{2} \mathrm{O}_{2}$ was added repeated at intervals until digestion was complete (as indicated by the change of the colour of the liquid to colourless. Few $\mathrm{ml}$ of water was added and boiled for a few 
seconds. The liberated phosphorus was evaluated by Fiske Subbarow method.

\section{Llipoprotein lipase}

Plasma lipoprotein lipase was estimated by the method of Cherry and Crandall ${ }^{20}$. The mixture, comprising of $1.0 \mathrm{ml}$ of enzyme source, $3 \mathrm{ml}$ of distilled water, $0.5 \mathrm{ml}$ of $0.33 \mathrm{M}$ phosphate buffer and $2.0 \mathrm{ml}$ of oil emulsion, was incubated at $37^{\circ} \mathrm{C}$ for $24 \mathrm{~h}$ and the reaction was arrested by the addition of $3 \mathrm{ml}$ of ethanol. Boiled enzyme source was used in the control instead of the fresh enzyme. The liberated free fatty acids were titrated with $\mathrm{NaOH}$ in the presence of $0.1 \mathrm{ml}$ phenolphthalein. One unit of activity is represented by $1 \mathrm{ml}$ of $0.05 \mathrm{~N} \mathrm{NaOH}$ required for the titration of the liberated acid from the olive oil due to hydrolysis by the lipases, and expressed as amount of glycerol formed in $\mathrm{mg} / \mathrm{ml}$.

\section{Histological studies}

Histological examination of tissue was carried out by Raghuramulu method ${ }^{21}$. Tissue fixation was carried out, immediately after removal from the body, with 10\% neutral buffered formaldehyde solution $(\mathrm{pH}$ 7.0). Tissue processing was carried out as per the schedule for dehydration, clearing and paraffin infiltration. The container was filled with melted paraffin and allowed to cool to form a block of paraffin with the tissue. The block was trimmed to remove paraffin overlaying the tissue, and sections of $5 \mu \mathrm{m}$ thickness were cut and mounted on clean glass slides which have been smeared with a drop of Mayer's egg albumin. It was then dried on a hot plate at about $50{ }^{\circ} \mathrm{C}$ for $30 \mathrm{~min}$, stained with hematoxylin and eosin, and examined under a light microscope.

\section{Statistical analysis}

Statistical analysis was performed by oneway analysis of variance (ANOVA) followed by Duncan's Multiple Range Test (DMRT). The results were expressed as mean \pm S.E.M for rats in each group. Values of $P<0.05$ were considered as significant.

\section{RESULTS}

Table 1 depicts the levels of plasma total cholesterol, triglycerides, free fatty acids (FFA) and phospholipids (PL) in normal and ISO-administered rats. Subcutaneous administration of ISO caused a significant ( $P$ $<0.05)$ rise in the levels of cholesterol $(34.9$ $\%)$, triglycerides (51.9\%), FFA (63.0\%) and $\mathrm{PL}(26.5 \%)$ in plasma of rats, compared with positive control rats. However, in NMpretreated rats that were given ISO, changes in the levels of cholesterol $(11.0 \%)$, triglycerides (21.7\%), FFA (53.7\%), and PL $(10.6 \%)$ were lower. NM pretreatment maintained these levels at near normal, i.e., $1.86 \%, \quad 5.54 \%, \quad 5.65 \%$ and $0.30 \%$ for cholesterol, triglycerides, $\mathrm{FA}$ and $\mathrm{PL}$ respectively.

Table 1: Effect of nutmeg extract (NM) and isoproterenol (ISO) on plasma lipid profile in normal and experimental rats

\begin{tabular}{ccccc}
\hline Group & Total cholesterol & Triglycerides & Free fatty acids & Phospholipids \\
\hline Control & $96.5 \pm 8.4^{\mathrm{a}}$ & $39.7 \pm 3.4^{\mathrm{a}}$ & $24.6 \pm 2.0^{\mathrm{a}}$ & $79.1 \pm 6.4^{\mathrm{a}}$ \\
ISO & $130.2 \pm 11.9^{\mathrm{b}}$ & $60.3 \pm 6.1^{\mathrm{b}}$ & $40.1 \pm 2.6^{\mathrm{b}}$ & $100.1 \pm 3.8^{\mathrm{b}}$ \\
NM & $94.7 \pm 7.8^{\mathrm{a}}$ & $37.5 \pm 2.1^{\mathrm{a}}$ & $23.2 \pm 1.2^{\mathrm{a}}$ & $78.9 \pm 5.7^{\mathrm{a}}$ \\
NM+ISO & $107.1 \pm 9.3^{\mathrm{c}}$ & $48.3 \pm 4.0^{\mathrm{c}}$ & $37.8 \pm 1.6^{\mathrm{c}}$ & $87.5 \pm 2.1^{\mathrm{c}}$ \\
\hline
\end{tabular}

Each value is a mean \pm S.E.M., $n=8$. Values not sharing a common superscript (a-c) differ significantly with each other $(P<0.05)$. 
In rats that received ISO, blood glucose level (see Figure 1) increased significantly $(P<$ 0.05 ) by $27.1 \%$, while glucose level in NMpretreated rats decreased insignificantly $(\mathrm{P}<$ 0.05 ) by $3.9 \%$ compared to control. On the other hand, in NM-pretreated rats that received ISO, blood glucose increased by 8.8 $\%$, when compared with control. Lipoprotein lipase activity data presented in Figure 2 show a significant $(P<0.05)$ decrease $(35.2$ $\%$ ) in the activity of the enzyme in rats that received ISO when compared with controls, while the enzyme level were was near normal in NM-treated (4.8\%) and NM-pretreated rats that also received ISO (4.35\%).

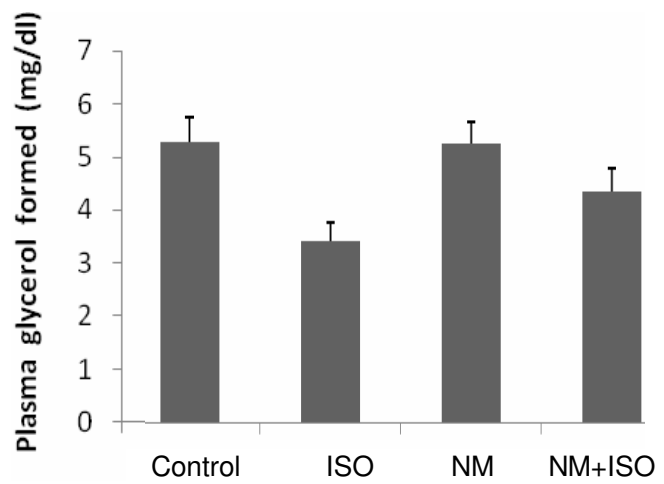

Figure 1: Blood glucose levels of control and experimental rats. (Each bar is mean \pm S.E.M., $\mathrm{n}=$ 8; ISO = isoproterenol; NMAET = Nutmeg extract).

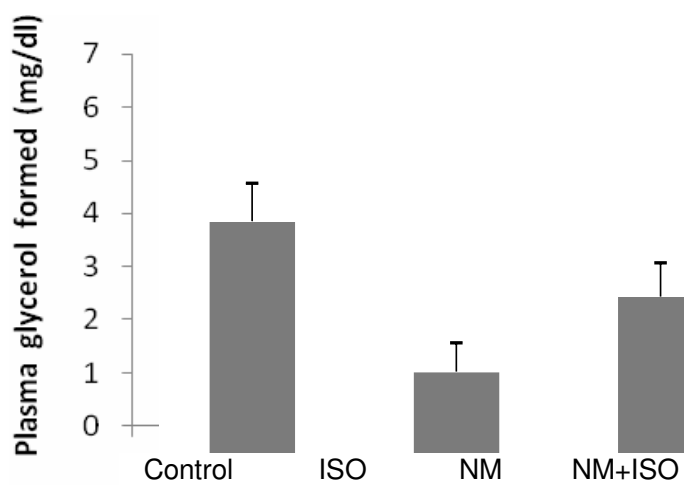

Figure 2: Changes in the activities of plasma lipoprotein lipase of control and experimental rats. (Each bar is mean \pm S.E.M., $n=8$; $I S O=$ isoproterenol; NMAET = Nutmeg extract).
Photomicrographs of histopathological sections of heart tissues of the rats are shown in Figure 3, The architecture is normal in control (Figure 3(a)) and NM-treated (Figure 3(c)) groups, but increased hyalinization occurred in rats treated ISO with only (Figure 3(b)) and minimal damage in the NM-pretreated rats that also received ISO (Figure 3(d)).

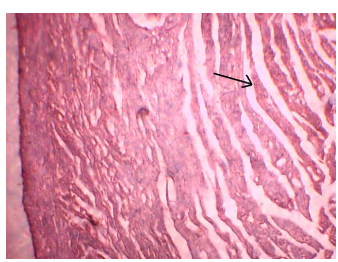

(a) Control rats

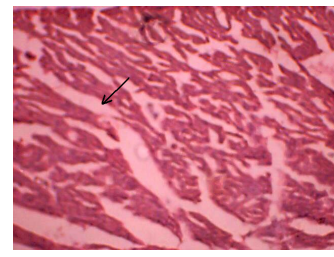

(c) NMAET-treated rats

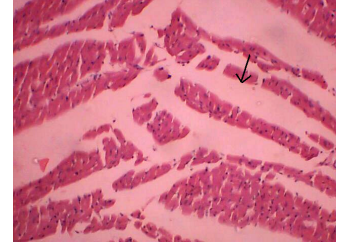

(b) Isoproterenol administered rats

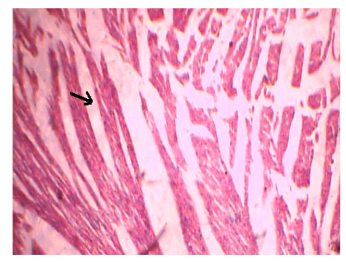

(d) NMAET-pretreated ISO administered rats
Figure 3: Photomicrograph of heart in normal and experimental animals. (Note: ISO = isoproterenol; NMAET = Nutmeg extract)

\section{DISCUSSION}

ISO produces relative ischemia or hypoxia due to myocardial hyperactivity and coronary hypotension $^{22}$, and induce myocardial ischemia due to cytosolic $\mathrm{Ca}^{2+}$ overload $^{23}$. In the group given ISO, blood glucose level increased compared to the control group. Increased levels could be due to enhanced glycogenolysis and lipolysis, through the activation of $\beta$-adrenergic receptor and phosphorylase kinase enzyme. Experimentally, ISO is capable of producing gross and microscopic myocardial necrosis and depletion of tissue enzymes in the heart. ISO-induced $\mathrm{MI}$ serves as a well standardized model to study the beneficial 
effects of many drugs and cardiac function since it mimics the clinical conditions of myocardial infarction due to ischemia in humans ${ }^{24}$. NM-pretreated rats administered ISO showed decrease (18.3\%) in blood glucose when compared to rats given ISO alone, This observation is in accordance with the earlier reports of Leigh et $\mathrm{al}^{13}$ and this may be due to the insulin-like biological activity of NM.

Lipids play an important role in CVD, not only by way of hyperlipidaemia and the development of atherosclerosis, but also by modifying the composition, structure and stability of cellular membranes ${ }^{25}$. ISO-treated rats showed an increase in the level of plasma lipids. The increased levels of plasma cholesterol and triglycerides observed in ISOinjected rats could be due to enhanced lipid biosynthesis by cardiac cyclic adenosine monophosphate $^{26}$. Plasma hypertriglyceridaemia, which was observed in ISO-treated rats, is due to decrease in the activity of lipoprotein lipase (Fig 2), resulting in decreased uptake of triglycerides from circulation. Hypertriglyceridaemia and increased levels of cholesterol in plasma might be responsible for altered cardiovascular functions which are often reported in ISO-induced myocardial infarction $(\mathrm{Ml})^{27}$.

Increase in plasma phospholipids in rats treated with ISO was observed. Increased peroxidation of membrane causes release of phospholipids and free fatty acids via phospholipase $\mathrm{A} 2{ }^{28}$. FFA is a substrate for microsomal lipid peroxidation. The higher level of plasma FFA in animals treated with ISO is due to increased lipolysis ${ }^{29}$. Paritha and Devi $^{26}$ have also reported an increase in plasma PL in ISO-treated rats. In the group treated with NM alone the levels of cholesterol, triglycerides, FFA and PL were maintained at near normal which could be due to effective quenching of free radicals by active phytochemicals in NM, such as flavonoids, saponins and cardiac glycosides ${ }^{30}$ in conjunction with its antioxidant properties ${ }^{31}$ thus reducing membrane lipidperoxidation, and hence decreased release of PL and FFA. The results of this study are in agreement with those of previous studies where it was reported that faecal excretion of cholesterol and $\mathrm{PL}{ }^{32}$ and decreased activity of lipoprotein lipase ${ }^{33}$ are responsible for decreased lipid levels in NM-pretreated rats that were given ISO.

\section{Histopathological studies}

The histopathological section of the control group (see Fig 3a) reveals normal architecture of the myocardium, with intact muscle fibres. The heart tissue of the rats given ISO (shown in Fig 3b) indicates hyalinization of muscle fibres, with focal cellular infiltration or necrosis of muscle fibres. Collection of inflammatory exudate is seen in the focal cells clearly, indicating that the heart tissue was damaged as a result of ISO administration. The heart tissue of NMtreated animals, displayed in Fig 3(c), shows no changes in cardiac structure and is similar to that of the control group. This indicates that NM did not damage the cardiac tissue. As Fig 3(d) reveals, there is minimal damage, with mild swelling of muscle cells and focal cardiac muscle fibres, in the NM-pretreated rats that received ISO. Thus NM has some protective effect on the myocardium against ISO.

\section{CONCLUSION}

This study shows that increased levels of lipids and blood glucose induced by ISO were decreased following pretreatment with NM, thus indicating that that the extract has some anti-hyperlipidaemic and hypoglycemic effects in rats with MI. Furthermore, NMpretreatment proved to be effective in reducing the extent of myocardial damage by decreasing blood lipid overload and this suggests that the extract could offer protection to the myocardium. 


\section{ACKNOWLEDGEMENT}

We acknowledge the gift of NM from M/S Chemiloids, Vijayawada, Andhrapradesh, India. We extend our heartfelt thanks to Prof M. Akthar of the Department of Statistics, S.K. University, Anantapur, A.P, India, for assisting with data analysis..

\section{REFERENCES}

1. Das DK, Maulik N. Protection against free radical injury in the heart and cardiac performance. In Sen, CK, Packer, L, Hanninen, O. (Eds.), Exercise and Oxygen Toxicity. Elsevier Science,Amsterdam 1995. 133-140.

2. Vaage J, Valen G. Pathophysiology and mediators of ischemia reperfusion injury with special reference to cardiac surgery. Scand. J. Thorac. Cardiovasc. Surg. 1993; 41: 1-18.

3. Wexler BC. Myocardial infarction in young vs old male rats; patho physiologic changes. Am. Heart J. 1978; 96: 70-80.

4. Nirmala C, Puvanakrishnan $R$. Isoproterenolinduced myocardial infarction in rats: functional and biochemical alterations. Med.Sci. Res. 1994; 22: 575-577.

5. Joff $M$, Robertson $A$. The potential contribution of increased vegetable and fruit consumption to health gain in the European Union. Public Health Nutr. 2001; 4: 893-901.

6. Tatsuya M, keiko J, Hirokazu K, Yasushi A, Hiroyuki S, Takahiro I, Kimio S. Hepatoprotective Effect of Myristicin from Nutmeg (Myristica fragrans) on Lipopolysaccharide/D-GalactosamineInduced Liver Injury. J. Agric. Food Chem. 2003; 51: 1560-1565.

7. Hyun Sook Kwon, Min Jung Kim, Hyung Jae Jeong, Min Suk Yang, Ki Hun Park, Tae Sook Jeong, Woo Song Lee. Low-density lipoprotein (LDL)antioxidant lignans from Myristica fragrans seeds. Bio organic\&Medicinal Chemistry Letters. 2008; 18:194-198.

8. Sharma M, Kumar M. Radioprotection of Swiss albino mice by myristica fragrans houtt. J. Radiat. Res. 2007; 48: 135-141.

9. Parle M, Dhingra D, Kullkarni SK. Improvement of mouse memory by Myristica fragrans seeds. JMed Food, 2004; 7(2): 157-161.

10. Olumayokun Olajide A, Franklin Ajayi F, Ambrosel khelar E..Olubusayo Awe S, Modupe Makinde $\mathrm{J}$, Akinola Alada AR. Biological Effects of Myristica fragrans (Nutmeg) Extract. Phytother. Res. 1999; 13:344-345.

11. Nandakarni AK, In: Dr. KM Nandakarni's Indian Materia and Medica. $3^{\text {rd }}$ edition. 2002, pp 830834. Popular prakashan pvt. Ltd., Mumbai.

12. Grover JK, Khandkar S, Vats V, Dhunnoo $Y$, Das D. Pharmacological studies on Myristica fragrans--antidiarrheal, hypnotic, analgesic and hemodynamic (blood pressure) parameters. Experimental Clinical Pharmacol. 2002. 24(10); 675-80.

13. Leigh Broadhurst C, Marilyn M. Polansky, Richard A. Anderson. Insulin-like Biological Activity of Culinary and Medicinal Plant Aqueous Extracts in vitro. J. Agric. Food Chem. 2000; 48: 849-852.

14. Rajadurai M, Stanely Mainzen PrinceP. Preventive effect of naringin on lipids, lipoproteins and lipid metabolic enzymes in isoproterenolinduced myocardial infarction in Wistar rats. J. Biochem. Mol. Toxicol. 2006; 20,191-197.

15. Trinder $P$. Determination of glucose by glucose oxidase method. Ann Clin Biochem. 1969; 6: 24-26.

16. Allian CC, Poon LS, Chan CSG, Richmand W, Fu $P$. Enzymatic determination of total plasma cholesterol. Clin Chem. 1974; 20: 470-475.

17. Fossati $P$, Principe $L$. Plasma triglycerides determined colorimetrically with an enzyme that produces hydrogen peroxide. Clin Chem. 1982; 28: 2077-2080.

18. Itaya K, Ui M. Colorimetric determination of free fatty acids in biological fluids. J. Lipid Res. 1965; 6, 16-20.

19. Connerty, Briggs and Eaton (1961). Determination of serum phospholipids, lipid phosphorus. In: Practical, clinical biochemistry, 4th edn, Varley $H(e d)$, CBS publishers, India, 319-320.

20. Cherry I, Crandall LA Jr. In: Nath RL. Practical Biochemistry in clinical medicine. $2^{\text {nd }}$ edition Academic publisher, Calcutta, India. 1990; 146148.

21. Raghuramulu N. Madhavan NK, Kalyan Sundaram S. A manual of laboratory techniques. National Institution of Nutrition, Hyderabad. 1983; 205206.

22. Bloom S, Davis D L. Calcium as mediator of isoproterenol-induced myocardial necrosis. Am J Pathol. 1991; 69:459-70.

23. Singal PK, Beamish RE, Dhalla NS. Potential oxidative pathways of catecholamines in the formation of lipid peroxides and genesis of heart disease.Adv Exp Med Biol. 1983; 161: 391-401.

24. Harada K, Futaka Y, Miwa A, Kaneta S, Fukushima $H$, Ogawa $N$. Effect of KRN 2391, a novel vasodilator, on various experimental anginal models in rats. Jpn. J. Pharmacol. 1993; 63, 35-39.

25. Rajadhurai M, Prince PSM. Comparative effect of Aegle marmelos extract and alpha-tocopherol on plasma lipids, lipid peroxides and cardiac marker enzyme levels in rats with isoproterenol-induced myocardial infarction. Singapore Med J. 2005; 46: 72-78.

26. Paritha A, Devi CS. Effect of $\alpha$-tocopherol on isoproterenol-induced changes in lipid and lipoprotein profile in rats. Ind $J$ Pharmacol. 1997; 29: 399-404.

27. Freedman DS, Gruchow HW, Anderson AJ, Rimm $A A$, Barboriak JJ. Relation of triglyceride levels 
to coronary artery disease: The Milwaukee Cardiovascular Data Registry. Am J Epidemiol. 1988; 127: 1118-1130.

28. Chien KR, Sherman SC, Mittnacht S Jr, Farber JL. Microsomal membrane structure and function subsequent to calcium activation of an endogenous phospholipase. Arch Biochem Biophys. 1980; 205: 614-622.

29. Mathew S, Menon PVG, Kurup PA. Changes in myocardial and aortic lipids, lipolytic activity and fecal excretion of sterols and bile acids in isoproterenol-induced myocardial infarction in rats. Ind J Biochem Biophys. 1981; 18: 131133.

30. Olaleye M.T, Afolabi C, Akinmoladun, Akindahunsi AA. Antioxidant properties of Myristica fragrans (Houtt) and its effect on selected organs of albino rats. African Journal of
Biotechnology. 2006; Vol. 5 (13), pp. 12741278.

31. Suchandra Chatterjee, Zareena Niaz, Gautam S, Soumyakanti Adhikari, Prasad Variyar $S$, Arun Sharma. Antioxidant activity of some phenolic constituents from green pepper (Piper nigrum L.) and fresh nutmeg mace (Myristica fragrans). Food Chemistry, 101:2007; 515523.

32. Sharma A, Mathur R, Dixit VP. Prevention of hypercholesterolemia and atherosclerosis in rabbits after supplementation of Myristica fragrans seed extract. Indian $J$ Physiol Pharmacol. 1995; 39(4): 407-10.

33. Ram A, Lauria $P$, Rajeev G, Sharma V.N. Hypolipidaemic effect of Myristica fragrans fruit extract in rabbits. J Ethnopharmacol. 1996; 55: 49-53. 